\title{
CHALLENGES AND SOLUTIONS IN TEACHING ADULTS: AN IN-COMPANY COURSE OF ENGLISH
}

\author{
Elena A. Bugreeva \\ St Petersburg State University, Russia \\ E-Mail: elena.a.bugreeva@yandex.ru
}

\begin{abstract}
Nowadays, companies tend to organize corporate courses and trainings upgrading their employees' skills. The article aims to analyze the key challenges that face a corporate English course and solutions for them. Further the author highlights the psychological and methodological peculiarities of teaching English to adult learners. This has been done by means of observation in class and reflection. A survey was conducted to prove some assumptions. The findings might be useful for the language instructors who teach English to adults.
\end{abstract}

Key words: lifelong learning, andragogy, in-company training, adult learners

\section{INTRODUCTION}

Today, the idea of sustainable lifelong learning has become important due to the evidence of high-speed globalization and increased volatility of the world. For Peter Jarvis, human learning is the combination of processes throughout a lifetime whereby the whole person - body (genetic, physical and biological) and mind (knowledge, skills, attitudes, values, emotions, meaning, beliefs and senses) - experiences natural and social situations, the content of which is then transformed cognitively, emotively or practically (or through any combination) and integrated into the individual person's biography resulting in a continually changing (or more experienced) person (Jarvis, 2009).

Now, professionals have to constantly develop and upgrade both their hard and soft skills to be ready to integrate into their professional community. The domination of English around the world is only expected to grow. According to the British Council's report The English Effect, English is currently spoken by 1.75 billion people worldwide one out of every four people on the planet. The group estimates that 2 billion people will be using English by 2020 (The English Effect, 2013). Hence, the English language skills are a prerequisite for joining the international (professional) community.

In the 1960s, the corporate Training and Development system emerged in the USA. The system provides employees with new soft and hard skills in order to enhance their efficiency and boost the profitability of the company they work for. In Russia, Training and Development came into being in the 1990s. Now, for instance, many companies offer to their employees an in-company course of English as a perk (together with other trainings). The course aims to prepare the staff to successfully deal with their professional tasks when working on site or in international project teams.

Submitted September $30^{\text {th }}, 2019$, accepted for publication November $1^{\text {st }}, 2019$

(C) 2019 by University of Niš, Serbia | Creative Commons License: CC BY-NC-ND 
Training methodology (the manner in which training is conducted) includes the methods, materials, techniques and sources to implement training, transfer new skills and knowledge to employees, and change their behavior and attitudes. Many times, implemented training does not meet intended objectives. Evaluation of training programs determines the relevance, effectiveness, and impact of activities in light of their objectives. Evaluation may enhance the quality of training and ensure long-term human resource development planning (Kirkpatrick, D.L., Kirkpatrick, J.D. (2006), Ibrahim, R., Boerhannoeddin, A., Bakare, K.K. (2017), Kucherov, D., Manokhina, D. (2017), Ludwikowska, K. (2018)). Many factors influence the quality of corporate trainings: motivation, organization, teaching formats and techniques, assessment and evaluation, and more. As an education specialist in an international company, I would like to analyze the English training methodology and share some solutions for the issues that may arise in teaching English to adult learners in a corporate English course.

\section{ANDRAGOGICAL APPROACH TO AdUlt EDUCATION}

Andragogy (the term was coined in the 1960s), the art and science of how adults learn, serves as a guideline for action in teaching to adults. Unlike teacher-centered pedagogy, andragogy considers learners as active participants in the organization of their learning. Generally, children have to learn in order to get prepared for the future; adults willingly learn to change their lives right away. Eduard C. Lindeman (1926), Edward L. Thorndike (1928, 1930), Malcolm S. Knowles (1973), David A. Kolb (1975), Peter Jarvis (1985, 1987, 1995, 1997, 2004, 2009) contributed much to the development of andragogic theories, principles, conceptions, models, and techniques. In Russia, adult learning was researched by Zh. Vitlin (1978), V. Podobed (2003), O. Barvenko (2004), S. Zmeev (2007), N. Kruglova (2012), G. Nizkodubov (2013), N. Lebedeva (2014), A. Verbitskii (2015), T. Esenkova (2015), K. Maltsev (2018), and many other talented scholars.

Andragogical approach to adult learning underpins a different educational practice based on the unique characteristics of adults as learners. Eduard C. Lindeman believes that adult education is a co-operative venture in non-authoritarian, informal learning the chief purpose of which is to discover the meaning of experience; a quest of the mind which digs down to the roots of the preconceptions which formulate our conduct; a technique of learning for adults which makes education coterminous with life, and hence elevates living itself to the level of an experiment (Lindeman, 1925).

\section{WHAT IS ADULT LEARNING LiKE?}

First of all, it is important to define an adult learner and their special features. Malcolm S. Knowles based his andragogical theory on four assumptions about adult learners: changes in self-concept; experience; readiness to learn; and orientation to learning (Knowles, 1984).

Adult learners might be supposed to lose their ability to learn. Edward Lee Thorndike believed that the ability to learn did not decline until the age of 35 , and only then at a rate of 1 percent per year (Thorndike, 1903). Now, it is clear that the speed of learning may decline along with aging, not the power of learning. Some adults may demonstrate a lower capability of memory, lower reactivity, or less effective cognition. Adults engaged in intellectual activity are more capable of learning than those who did not study since their school. 
Adults are often more rigid when acquiring a new cultural and linguistic reality. An example is the speaking technique of overestimation in feedbacking. Russian learners do not find it important to feedback with the words and expressions like Good idea! Great! Awesome! Perfect! in a conversation. In fact, this is because Russian speakers rarely do this in their native language.

Adults are often afraid of failure. Some adults may be confounded by the minimization of their status as a professional to that of a learner. That is why their active role in their real (professional) life should not become passive in learning, which complies with the andragogical approach to learning. For E. C. Lindeman, authoritative teaching, examinations which preclude original thinking, rigid pedagogical formulae - all of these have no place in adult education (Lindeman, 1926).

M. S. Knowles noted that adult learners need to know why they are learning something; learn through doing; learn best when the subject is of immediate use; prefer social interaction; want to use their life experiences in the classroom; want to integrate new ideas with existing knowledge. Hence, the key principles for adult learning are as follows.

- Adults need to be involved into the planning and evaluation of their instruction (instructors should explain why specific knowledge and skills are taught).

- Learning activities (instead of memorization) should be based on experience (both positive and negative).

- Adults are most interested in learning when subjects have immediate impact to their job or personal life.

- Adult learning is problem-centered rather than content-oriented (Knowles, 1973; Kearsley, 2010).

\section{TEACHING TO A GROUP OF ADULT LEARNERS}

Language instructors should consider the greater diversity in a group of adult learners. Adults are not usually grouped by their age (like schoolchildren). This results in a greater diversity of their experiences, worldviews, and attitudes. Besides, Irina Zimniaia finds it important to take into consideration learners' national features, gender, age, status, and individual psychological peculiarities (Zimniaia, 2003).

There are three general learning styles for providing information: visual, auditory, and kinesthetic or tactile. In order to make teaching effective and prevent conflicts, it is important to design a lesson including activities for all the types. Language instructors should offer handouts, pictures, graphs, charts, diagrams, and writing on the whiteboard for visual learners. Auditory learners will be interested in discussions, storytelling, examples, case studies, oral reports and presentations. Kinesthetic or tactile learners prefer role playing, simulation games, and practicing what they are learning. While people generally prefer one learning style, they simultaneously process information through multiple senses. As a result, the retention of learned material is enhanced if presentations are multisensory (visual and auditory components) in combination with interactive activities (Rasmussen, 2015).

In his Learning Style Inventory (LSI), David A. Kolb offered to distinguish four types of learners according to their learning preference: a converger (active experimentation - abstract conceptualization), an accommodator (active experimentation - concrete experience), an assimilator (reflective observation - abstract conceptualization), and a diverger (reflective observation - concrete experience) 
Ideally, according to E. C. Lindeman, this should be 'small groups of aspiring adults who desire to keep their minds fresh and vigorous; who begin to learn by confronting pertinent situations; who dig down into the reservoirs of their experience before resorting to texts and secondary facts; who are led in the discussion by teachers who are also searchers after wisdom and not oracles: this constitutes the setting for adult education, the modern quest for life's meaning' (Lindeman, 1926).

\section{Motivation}

In business education, employees are usually highly motivated by the company's policy, a need for making career, pay rise, mobility, a capability to communicate with customers, and/or working on site. The survey conducted in an IT company shows that most of the employees (48 out of 50 people) take a corporate course of English to deal with their professional tasks within international projects ( 2 out of 50 people hope that strong English skills will help them get promoted). Thus, an English course must be oriented to the specific actions and procedures employees are engaged in. For this, the education specialist responsible for an in-house English course should realize what product or service the company offers.

However, even strong motivation can be ruined by many factors. Adult learning is significantly determined by temporal, social, professional aspects and their daily life (Zmeev, 2007). Adults value their time because it is always limited. They have to squeeze the English classes into their work schedule. They have to miss classes because of urgent tasks, business trips, sick leave, or vacation. In is also difficult to find free time for homework or individual work. These factors make learning more stressful.

As a solution, language sessions should be as intensive as possible to fully engage adults. The course could be subdivided into modules that are not interconnected with each other. Or, each language session could be designed as an individual module aimed to reach a particular 'here and now' goal. All language sessions should be closed into a loop. The syllabus should be designed like a spiral ascending on each turn. Those who missed the class will catch it up without breaking the learning continuum. Apart from this, the materials and activities selected for a language session should enhance the effectiveness of learning in the classroom.

Many adult learners come to corporate courses with the 'school-like' (pedagogical) paradigm of learning: they totally rely on the instructor and reject their active participation. On the contrary, the andragogical model of learning implies learners' enthusiasm. The pedagogical paradigm is difficult to change. At the same time, adults do not often consider many activities used to motivate learners in school. As an example, many adult learners dislike playing games in classroom. Psychologically, their unwillingness may be explained by the stereotype that games are for children. Adults think they waste time rather than study when playing games. Many adults ignore writing tasks, note taking, or writing on the whiteboard.

As mentioned above, adult learners can be rather rigid in acquiring another communication culture. Communication in English differs much from that in Russian. The key communication skills in English are: indirect style and politeness; active listening and feedbacking; paraphrasing; overestimation; and modifying. This is the greatest challenge for adult Russian speakers to change their communication style. They find it difficult to join 
discussion or lead a meeting and, specifically, interrupt, ask a question, give feedback, check and double check information, or pay a compliment.

\section{APPROACHES TO AdULT LEARNING}

For E. C. Lindeman, because adult education is free from the yoke of the subjecttradition, its builders are able to experiment boldly even in the sacrosanct sphere of pedagogical method. Indeed, if adult education is to produce a difference of quality in the use of intelligence, its promoters will do well to devote their major concern to method and not content (Lindeman 1926).

As adults might be confused with the contradictions between abstract notions and practical real (professional) life, the Experiential Learning Model is the most relevant in adult learning. David A. Kolb and Ron Fry developed the Experiential Learning Model (ELM) in the early 1970s. The method includes: concrete experience; observation of and reflection on that experience; formation of abstract concepts based upon the reflection; and testing the new concepts.

E. C. Lindeman considers the learner's experience as the resource of highest value in adult education. If education is life, then life is also education. Too much of learning consists of vicarious substitution of someone else's experience and knowledge. Psychology is teaching us, however, that we learn what we do, and that therefore all genuine education will keep doing and thinking together (Lindeman, 1926). Adults' life experiences may be shared in storytelling, case studies and dilemma solving.

Apart from adults' life experiences and knowledge, Experiential Learning means their active participation in learning. Active participation implies any activity that gets your learners involved: small group discussions, experiments, role playing, skits, building something at their table or desk, writing or drawing something. The activities keep people energized, especially activities that involve getting up and moving about. However, research shows that adult learners' retention rate increases significantly when they are engaged in active learning methods (Rasmussen, 2015).

Active participation in learning is demanding but rewarding. The problem is that adult learners do not often have strong soft skills in their native language. Many adult learners are struggling to learn how to strike up a conversation and keep it going (they often fail even in Russian). So, they often keep silent or answer with one word or sentence when asked in English. They often explain this as follows: "I don't know what to say even in Russian". At the same time, active speaking practice is the clue to successful and effective learning.

The employees of the company, where I teach English, were also asked what topics they like or dislike discussing in English classes. The survey shows that adults do not like talking about themselves (22\%), latest news $(20 \%)$, their job (14\%), traditional topics in textbooks, like your favorite book or movie (12\%), and the topics they are not concerned of $(6 \%)$.On the other hand, $26 \%$ answered that any topic could be discussed even if they are not interested in that.

Edward Lee Thorndike stated the law of effect, which says behaviors that are followed by good consequences are likely to be repeated in the future. Thorndike's law of exercise includes the law of use and the law of disuse. Law of use - the more often an association is used the stronger it becomes. Law of disuse - the longer an association is unused the weaker it becomes (Thorndike, 1903). However, adults often refuse to drill 
something. In learning vocabulary, it is important to keep using new words and expressions in speaking practice. In learning grammar, learners have to practice new grammar tools. Adults tend to get along with what they had learnt before. Thus, the language instructor should regularly support grammar and vocabulary drilling. Instead of lecturing, this should be done through provoking relevant contexts and solving dilemmas.

\section{TyPES OF ACTIVITIES IN TEACHING ENGLISH TO ADULTS}

Edward L. Thorndike believed that instruction should pursue specified, socially useful goals. How to shape the content of an English course to make the learning relevant to what employees do in the company? For this, language instructors and trainers must know what in particular this or that job involves in the company. As an example, a business analyst is responsible for communicating with customers: asking for and analyzing their requirements. So, a business analyst must know how to make a request, clarify, deal with conflicts politely, and more. Technical staff has to learn how to comprehend and explain a technical task, take part in a sinc-up meeting, ask for and clarify information, and so forth. All employees need to know how to talk over the phone, write e-mails, deliver a presentation, and take part in meetings. This requires the communicative approach to teaching a corporate English course.

Another matter of concern is the activities to offer to adult students. To provide a supportive learning environment, it is reasonable to plan activities where adult learners can direct their learning process. Peter Jarvis thinks that teachers should endeavor to create types of relationship with students that enable them to decide for themselves on what is in their own best interest in dialogue with the teachers, where it is appropriate. The concern lies in the dialogical relationship between teachers and learners rather than the content of what is taught (Jarvis, 1997). As an example, when discussing a news story (I offer BBC Learning English) I ask my adult learners to research into the problem discussed. I always give some options. One of the latest stories is about the new safety standards for touristic boats on the Themes, which can send many boats out of the business. I ask to get ready to discuss either the safety standards (for those interested in technical matters); or the most popular routs in London (for those who are keen on tourism); or to characterize different types of boats (for those who are in love with sailing, yachting, and more); or to see if the boats in St Petersburg meet the safety standards.

E. C. Lindeman believes that the approach to adult education will be via the route of situations, not subjects... Every adult person finds himself in specific situations with respect to his work, his recreation, his family-life, his community-life et cetera situations which call for adjustments. Adult education begins at this point. Subject matter is brought into the situation, is put to work, when needed. Texts and teachers play a new and secondary role in this type of education; they must give way to the primary importance of the learner... The situation-approach to education means that the learning process is at the outset given a setting of reality. Intelligence performs its functions in relation to actualities, not abstractions (Lindeman, 1926).

In a corporate English course, the language instructor should offer such activities that make learners enthusiastic and immediately lead them to a result. It is efficient to explain what and why adults are learning and link the knowledge or skill to their real life. As an example, when my adult learners studied the peculiarities of e-mailing in English they 
were involved into a real-like work. Everybody got a text where different pieces of information were missing. The learners were asked to inquire the information from their groupmates. The other learners had to respond all the e-mails to either send the missing information or explain that they do not have it. The more people take part in the activity the more they practice. Then, the language instructor should comment on the style, format and grammar mistakes in the e-mails.

Practice shows that adult learners effectively deal with the tasks organized as an instruction or algorithm. A structured presentation is one of the best formats for developing adult learners' speaking skills. It does not take long to explain the structure of a presentation: an introduction, the main part, a conclusion, and Q-and-A session. Then, they learn standard phrases to start, keep on tracking, and finish the presentation. It is important to highlight that Q-and-A session is part of any speaking in public and skillful dealing with questions (especially difficult ones) is vital. Handling the format of a structured presentation makes it easier for adult students to feel free when speaking. To practice reactivity in dialogues, a telephone talk is relevant as another relatively structured communication.

\section{ASSESSMENT AND EvaluATION}

For E. C. Lindeman, adult education happily requires neither entrance nor exit examinations. Adult learners attend classes voluntarily and they leave whenever the teaching falls below the standard of interest. What they learn converges upon life, not upon commencement and diploma. The external tokens of learning are removed so that the learning process may stand or fall on its intrinsic merits (Lindeman 1926).

In corporate training, a relevant assessment and evaluation system should be developed. In my opinion, formative assessment is preferable because it is diagnostic and remedial; it provides effective feedback; it makes teaching learner-oriented and involves adults in their own learning; it influences the motivation and self-esteem of adult learners; instructors are able to adjust their instructional design; it considers varied learning styles. It is crucial that adult learners understand the criteria they have to meet in the end.

To compare, summative assessment marks the learner's performance according to a scale or set of grades. The most relevant in adult learning is the graded tests in the international testing systems. As an example, the IELTS bands of criteria reflect the real-life language competence. More so, many adults might have to take the test to work or study in other countries. In our office, many employees pass IELTS to work on site.

Thus, we need assessment in a corporate English course in order to show employees' readiness for real life rather than for a test. Employees' English skills evaluation is only applicable as a feedback to a team lead's request, which is necessary for the right placement.

\section{CONCLUSION}

The efficiency of the corporate language course depends on both the learners and the instructor. It is important for learners to swap from the pedagogical to andragogical approach to learning. As adult learning in the classroom outweighs their individual work, this demands much intellectual, physical and moral effort from the language instructor in class. When teaching English to adults, the language instructor should know: the psychology of adults; the key ideas in andragogy; the basics of instructional design; and 
ESP methodology. As companies usually order a course of Business English or English for Special Purposes (Legal English, English for Accountants, English for IT specialists), this implies life-long self-development and self-education from the language instructor (sometimes, additional qualification).

\section{REFERENCES}

Barvenko, O. Psychological Barriers in Teaching Foreign Languages to Adults. Rostov-onDon, 2004.

Caffarella, R., Barnett, B. "Characteristics of Adult Learners and Foundations of Experiential Learning.” New Directions for Adult and Continuing Education. 62 (1994): 29-42. JosseyBass, Inc. Publishers.

Esenkova, T. "Pedagogical Techniques in Adult Learning: Methodology, Content, Effectiveness." Fundamental Research 2-7(2015): 1483-1488<http://www.fundamentalresearch.ru/ru/article/view?id=37178> (11.05.2019).

G. Nizkodubov "The Place and Role of English Course in Lifelong Learning." Tomsk, 2013. <https://cyberleninka.ru/article/n/mesto-i-rol-kursov-angliyskogo-yazyka-....> September 2019).

Ibrahim, R., Boerhannoeddin, A., Bakare, K. K. "The Effect of Soft Skills and Training Methodology on Employee Performance." European Journal of Training and Development, 41(4)(2017): 388-406.

Jarvis, P. The Sociology of Adult and Continuing Education. Beckenham: Croom Helm, 1985.

Jarvis, P. Adult Learning in the Social Context. London: Croom Helm, 1987.

Jarvis, P. Adult and Continuing Education. London: Routledge, 1995.

Jarvis, P. Ethics and Education for Adults in Late Modern Society. Leicester: NIACE, 1997.

Jarvis, P. Adult Education \& Lifelong Learning. London: Routledge Falmer, 2004.

Jarvis, P. Learning to be a Person in Society. London: Routledge, 2009.

Kearsley, G. Andragogy (M. Knowles). The Theory into Practice Database. 2010.

Kirkpatrick, D. L., Kirkpatrick, J. D. Evaluating Training Programs. The Four Levels. 3rd edition. San Francisco: Berrett-Koehler Publishers, 2006.

Knowles, M. S. The Adult Learner: a Neglected Species. Houston, TX: Gulf Publishing Co., 1973.

Knowles, M. S., Holton III, E. F., Swanson, R. A. The Adult Learner: the Definitive Classic in Adult Education and Human Resource Development. 2005.

Knowles, M. S. Informal Adult Education. New York: Association Press, 1950.

Knowles, M. S. A History of the Adult Education Movement in the USA. New York: Krieger, 1962.

Knowles, M. S. The Modern Practice of Adult Education. Andragogy versus Pedagogy. Englewood Cliffs: Prentice Hall/Cambridge, 1970, 1980.

Kolb, D. A., Fry R. Toward an Applied Theory of Experiential Learning. In C. Cooper (ed.) Theories of Group Process, London: John Wiley, 1975.

Kucherov, D., Manokhina, D. "Evaluation of Training Programs in Russian Manufacturing Companies." European Journal of Training and Development. 41(2)(2017): 119-143.

Lebedeva, N. "Modern Approaches to Adult Learning." Siberian Psychological Journal 51(2014): 65-72. 
Lindeman, E. C. What is Adult Education? New York: Columbia University, Butler Library Lindeman Archive, 1925.

Lindeman, E. C. “Adult Education: a Creative Opportunity.” Library Journal, 50(1925): 445-447.

Lindeman, E. C. “Adult Education.” New Republic, 54(1925): 7-8.

Lindeman, E. C. "The Meaning of Adult Education.” New York: New Republic, 1926. (Republished in 1961 by Harvest House; in 1989 by The Oklahoma Research Center for Continuing Professional and Higher Education.)

Lindeman, E. C. “The Sociology of Adult Education.” Education Sociology, 19(1945): 4-13.

Ludwikowska, K. "The Effectiveness of Training Needs Analysis and its Relation to Employee Efficiency." Zeszyty Naukowe Politechniki Poznańskiej. Organizacjai Zarządzanie. 77(2018).

Maltsev, K. "Valuable Staff: How to Build an Effective Training System in a Company." Alpina Publisher, 2018.

N. Kruglova "Developing Communicative Competence in Adults Learning Foreign Languages within an Additional Vocational Education Program.” Moscow, 2012. <http://www.dissercat.com/content/formirovanie-kommunikativnykh-kompetent...> September 2019).

Practical Andragogy. Book 1. Contemporary Adaptive Systems and Techniques for Adult Learning. V. Podobed, A. Maron (Ed.). St Petersburg, 2003.

Rasmussen, C. Adults as Learners: Effective Teaching Strategies. Workforce Solutions Conference. University of Minnesota. June 23-24, 2015.

The English Effect: The Impact of English. British Council, 2013. <https://www. britishcouncil.org/sites/default/files/english-effect-report-v2.pdf> (28 August 2019).

Thorndike, E. L. Educational Psychology. 1903.

Thorndike, E. L., Bregman E. O., Tilton J. W., Woodyard E. Adult Learning. New York: The Macmillan Company, 1928.

Verbitskii, A. "Adult Learning in the Lifelong Learning System.” Lifelong Learning: Lifelong Learning for Sustainable Development. 2015. <https://cyberleninka.ru/article/n/ obrazovanie-vzroslyh-v-sisteme-nepreryvnogo-obrazovaniya> (8 September 2019)

Vitlin, Zh. Teaching Foreign Languages to Adults (theory and practice). Moscow: Pedagogika, 1978.

Zimniaia, I. "Key Competences - a New Paradigm of Education Results." Higher Education Today 5(2003): 74.

Zmeev, S. Andragogy: Adult Learning Theory, History and Techniques. Moscow: PER CE, 2007. 